\title{
AN EMPIRICAL MODEL FOR ESTIMATING REMEDIATION COSTS AT CONTAMINATED SITES
}

\author{
MARTIN M. KAUFMAN ${ }^{1, *}$, DANIEL T. ROGERS ${ }^{2}$ and KENT S. MURRAY ${ }^{3}$ \\ ${ }^{1}$ Department of Earth and Resource Science, University of Michigan-Flint, USA; ${ }^{2}$ Amsted \\ Industries Incorporated, USA; ${ }^{3}$ University of Michigan-Dearborn, USA, \\ (*author for correspondence, e-mail: martyk@umflint.edu; Tel.: +1 (810) 762-3355, \\ Fax: +1 (810) 762-3153)
}

(Received 14 February 2005; accepted 25 June 2005)

\begin{abstract}
A model for estimating the remediation costs at contaminated sites is developed, in which the predictor variable is a composite of surface, subsurface, and contaminant risk factors. Calibration of the model is performed at 83 sites in an urbanized watershed with diverse surface geology in southeastern Michigan. These test sites exhibited different extents of contamination, including some where only soil was contaminated, and others where soil and groundwater were contaminated. The model was then applied to 79 sites with multiple contamination extents within different watersheds in North America, Europe, Australia, and Africa. The results indicate a very high correlation between the estimated and actual remediation costs at these sites. This model thus has the potential for providing reliable estimates of remediation costs across a broad array of soil and groundwater contamination scenarios, including dense nonaqueous phase liquid (DNAPL) contamination in sandy soil and lead in clay soil.
\end{abstract}

Keywords: brownfields, contaminant risk factors, groundwater contamination, modeling risk, remediation cost estimation

\section{Introduction}

Brownfield sites are a common occurrence in old urban areas, especially those with a history of heavy industrial activity. Because brownfields are essentially abandoned, idled, or underutilized industrial or commercial facilities (US EPA, 1997), many sites have existing environmental contamination, which can complicate plans for redevelopment. The process of brownfield contamination results from a sequence of anthropogenic and natural activities and processes involving a contaminant source, its mobilization through the soil (transport action), and its ultimate site of deposition (sinks). These substances may be transported over time, or stay relatively near their release location. Sources of contamination at brownfields are the human activities performed primarily on the surface that release toxic substances into the environment.

There is a tremendous amount of land represented by brownfields in the United States, with estimates of the number of sites ranging from 500,000 to 1 million (Bartsch et al., 1991; OTA, 1995; Simons, 1999). This number is likely to increase, 
since a broader definition of brownfields has been adopted with the passage of the Small Business Liability Relief and Brownfields Revitalization Act (SBLRBRA) of 2001 (PL 107-118). The broader list of contaminated areas now eligible for financial assistance includes those sites recognized by the U.S. President where there are opportunities to protect human health, the environment, or to promote economic development. In addition, lower-risk sites contaminated by petroleum and mine scarred lands are also included under the new legislation (PL 107-118, Section 211).

The magnitude of brownfield contamination, and the recognition that brownfield redevelopment provides positive economic benefits to communities has created an extensive literature on the economic and environmental aspects of brownfield redevelopment (Singer, 2000; Irwin, 2001). Because of the needs to evaluate contaminant plume extent, design monitoring networks, and estimate remediation costs groundwater modeling has increased substantially since the 1980s (Bedient $e t$ al., 1999). Recent modeling approaches have also incorporated decision analysis and support systems to help improve the estimation of remediation costs (Wang and McTernan, 2002; Aziz et al., 2003). However, a systematic evaluation of the existing and potential risks within an environmental geology framework and their relationship to actual remediation costs has only recently evolved (Kaufman $e t a l$., 2003). Rogers et al. (2005, in press) has refined the risk assessment procedure by combining the risks from surface, subsurface, and specific contaminants to develop a model to assess groundwater vulnerability. In this effort, the toxicity, mobility, and persistence of specific contaminants within four contaminant categories: dense nonaqueous phase liquids (DNAPLs), light nonaqueous phase liquids (LNAPLs), polynuclear aromatic hydrocarbons (PNAs), and lead were combined to create a Contaminant Risk Factor (CRF) score. This score is then added to existing methods for assessing the estimated surface and subsurface risks.

\subsection{STUDY AREA}

The study area is the Rouge River watershed in southeastern Michigan (Figure 1). This region is located on the southeastern edge of the Michigan Basin, a $316,000 \mathrm{~km}^{2}$ area composed of sedimentary rocks - primarily limestones, shales, and sandstones. These sedimentary rocks are Paleozoic in age, and rarely exist as natural outcrops because of the presence of a thick deposit of glacial drift in the region. Beneath the study area, the Paleozoic rocks range from 425 to 730 meters thick and gently dip toward the center of the basin to the northwest. The depth to bedrock ranges from more than 110 meters in the northwestern portion of the study area to less than 15 meters in the southeastern (Rieck, 1981).

Sediments of Pleistocene age overlie the Paleozoic rocks of the Michigan Basin. This forms an unconformity where deposition had not occurred for approximately 280 million years. This unconformity indicates that following the late Paleozoic, the Michigan Basin was uplifted, exposed, and eroded (Dorr and Eschman, 1988). 


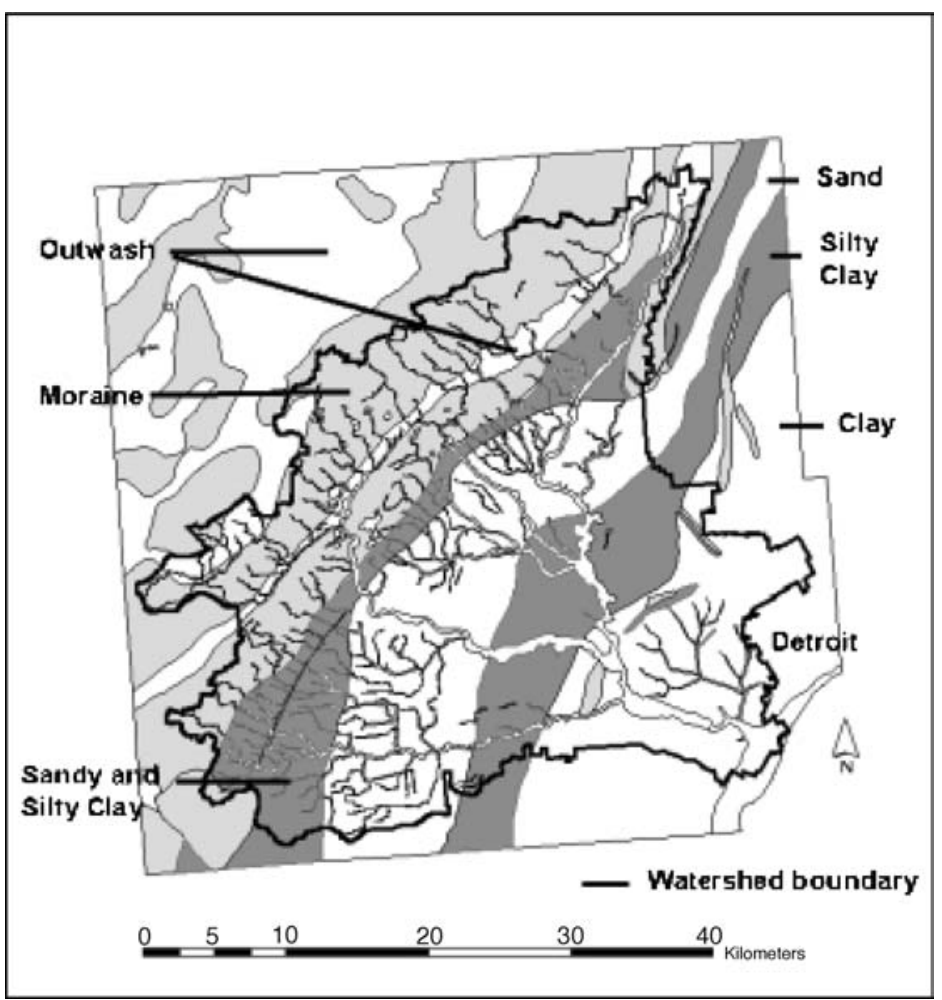

Figure 1. Study area.

Surficial geology in Michigan is dominated by glacial sediments that are typically over 60 meters thick and, at some locations more than 300 meters thick (Rieck, 1981). These glacial sediments were deposited during the Pleistocene Epoch by the Wisconsinan stage of glaciation, and consist of outwash, moraine, and beach, bar and lake deposits (Farrand, 1988). Varied and complex lithologies are exhibited within these deposits, which include coarse gravels, fine-grained sands, and clays (Bergquist and MacLachlan, 1951; Mozola, 1969; Rieck, 1981, 1981a).

Five distinct near-surface geologic units have been identified within the study area (Leverett, 1911; Sherzer, 1916; Farrand, 1982; Rogers, 1996). The units are classified by their composition and include moraine, sandy clay, sand, sandy and silty clay, and clay (Figure 1). The study area is one of the most highly urbanized and industrialized drainage basins in the country. This unique combination has resulted in thousands of sites of environmental concern. These sites represent a diverse combination of soil and/or groundwater contamination and surface geology that creates an unparalleled opportunity to evaluate the remediation process and its associated costs across a wide array of geological and contamination interactions. Table I summarizes the characteristics of the contamination, surface geology, and remediation costs at the sites within the Rouge River watershed. 
TABLE I

Summary of Rouge River site characteristics

\begin{tabular}{|c|c|c|c|c|c|c|}
\hline $\begin{array}{l}\text { Contaminant } \\
\text { of concern }\end{array}$ & $\begin{array}{l}\text { Number } \\
\text { of sites }\end{array}$ & $\begin{array}{l}\text { Soil } \\
\text { type }\end{array}$ & $\begin{array}{l}\text { Number } \\
\text { of sites }\end{array}$ & $\begin{array}{l}\text { Geologic } \\
\text { setting }\end{array}$ & $\begin{array}{l}\text { Average } \\
\text { cost }(\$ / \mathrm{Kg})\end{array}$ & $\begin{array}{l}\text { Average extent of } \\
\text { contamination from } \\
\text { source (meters) }\end{array}$ \\
\hline \multirow[t]{5}{*}{ DNAPL } & \multirow[t]{5}{*}{23} & Moraine & 4 & Glacial & 145,000 & 625 \\
\hline & & $\mathrm{SSC}^{\mathrm{a}}$ & 3 & $\mathrm{GL}^{\mathrm{b}}$ & 3,260 & 42 \\
\hline & & $\mathrm{SC}^{\mathrm{c}}$ & 2 & GL & 1,366 & 50 \\
\hline & & Sand & 8 & GL & 116,400 & 1,012 \\
\hline & & Clay & 6 & GL & 721 & 30 \\
\hline \multirow[t]{5}{*}{ LNAPL } & \multirow[t]{5}{*}{27} & Moraine & 5 & Glacial & 6,411 & 270 \\
\hline & & SSC & 4 & GL & 669 & 43.5 \\
\hline & & SC & 3 & GL & 518 & 45.6 \\
\hline & & Sand & 8 & GL & 2,627 & 328 \\
\hline & & Clay & 7 & GL & 319 & 38 \\
\hline \multirow[t]{5}{*}{ PNAs } & \multirow[t]{5}{*}{22} & Moraine & 0 & Glacial & - & - \\
\hline & & SSC & 2 & GL & 203 & 32 \\
\hline & & $\mathrm{SC}$ & 7 & GL & 841 & 27.4 \\
\hline & & Sand & 5 & GL & 444 & 30 \\
\hline & & Clay & 8 & GL & 964 & 16.3 \\
\hline \multirow[t]{5}{*}{ Lead } & \multirow[t]{5}{*}{11} & Moraine & 0 & Glacial & - & - \\
\hline & & SSC & 2 & GL & 538 & 42 \\
\hline & & $\mathrm{SC}$ & 3 & GL & 230 & 25 \\
\hline & & Sand & 2 & GL & 442 & 27 \\
\hline & & Clay & 4 & GL & 68.7 & 52.5 \\
\hline
\end{tabular}

${ }^{\mathrm{a}} \mathrm{SSC}=$ Sandy and silty clay.

${ }^{\mathrm{b}} \mathrm{GL}=$ Glacial lacustrine.

${ }^{\mathrm{c}} \mathrm{SC}=$ Sandy clay.

The objectives of this research are: (1) to develop a conceptual model for estimating the remediation costs at contaminated sites; (2) to calibrate this model within the urbanized River Rouge watershed in the United States which exhibits diverse surface geology and multiple extents of contamination (surface soil and groundwater); and, (3) to validate this model on additional sites of contamination within different watersheds across North America, Europe, Australia, and Africa, also exhibiting diverse surface geology and multiple extents of contamination. To achieve these objectives, this paper presents a simple linear regression model for estimating the remediation costs at contaminated sites. The independent predictor variable is a composite construct consisting of the CRF scores developed by Rogers et al. (2005 in press) combined with the distance (extent) of the contamination and the mass of the contaminant recovered or remediated. 


\section{Materials and Methods}

Models attempt to reveal the truth about a system (Hassan, 2004), but they can only simulate what is occurring. A successful model will accurately represent the main components of the system and depict the sequence of events contributing to the process being studied. Moreover, a good model is simple. Thus, the first step in model development is often a graphical "process model".

Equation (1) represents a process model for estimating the remediation cost at contaminated sites.

Remediation Cost $=\mathrm{f}($ total risk: contaminant characteristics

$$
\begin{aligned}
& \rightarrow \text { contaminant risks } \rightarrow \text { release into environment } \\
& \rightarrow \text { surface risks } \rightarrow \text { geological environment } \\
& \rightarrow \text { associated geologic risks } \\
& \quad * \text { plume extent and contaminant mass) }
\end{aligned}
$$

The remediation costs used in this study represent the total costs in U.S. dollars. The accounting period for these costs encompasses the period from the initial site investigation to case closure. Remediation costs are conceived as a function (f) of total risk, which consists of several sequentially occurring subcomponents. The risks begin with specific contaminants having chemical and physical properties (contaminant characteristics) which create varying potential and actual contaminant risks. When stored, the risks are potential. If these substances are released by human activities on the surface, the contaminant risks become real. Surface risks represent the probability that a contaminant will be released by human activities and come into contact with the ground surface. This probability varies by the type of activity performed; for example, there are higher risks of contaminants being released into the environment from metal processing activities than from bakeries. Once on the surface, the geological environment consisting of soil composition, the depth to groundwater, and other aquifer characteristics create the associated geological risks as the contaminant migrates. Costs will increase as the plume extent and the measured amounts of contaminant mass increase.

To operationalize the model, each subcomponent is described, including the theoretical basis for the analytical procedures used to derive the risk values associated with the contaminants within their surface and subsurface environments. This is followed by an overview of the procedures used to calibrate and test (validate) the model.

\subsection{CONTAMinant CHARACTERISTics}

Because contaminants released into the environment are often mixtures of several and occasionally hundreds of chemical compounds (e.g., gasoline), an 
understanding of the physical chemistry of each of the chemical constituents and the geologic environment to which they are released is necessary to evaluate their fate and transport. After transport, these compounds remain at different locations or sinks for different time periods. Examples of sinks include the near-surface soil, and groundwater, where contaminants will be transported at rates dependent upon (1) the specific physical chemistry of the contaminant and (2) local aquifer relationships to other sinks including inland lakes and streams, or the ocean.

The critical physical/chemical attributes that influence contaminant risk are associated with migration potential, and these include: (1) solubility, (2) vapor pressure, (3) density, (4) stability, (5) persistence, and (6) adsorption potential (US EPA, 1989, 1996; Wiedemeier et al., 1999). While toxicity is an important factor in evaluating risk, mobility and persistence are also important because chemicals have the ability to migrate from their points of release in the environment to points of human exposure, such as a drinking water supply or surface water- which could be more than a kilometer away from the release point.

\subsection{CONTAMINANT RISKS}

Contaminant risk arising from the presence of a specific compound can be characterized as a combination of three criteria which include (1) toxicity or potency, (2) mobility, and (3) persistence (US EPA, 1989). In general, contaminants released into the environment only present a risk to humans if there is a completed exposure pathway. Therefore, toxicity is not the only factor that should be considered when evaluating the risk posed by the presence of a particular chemical compound (US EPA, 1989). Consideration should also be given to how mobile and how persistent a chemical is when it is released into the environment. In other words, a chemical that is extremely toxic to humans may not present as much risk as a chemical that is not as toxic but is mobile and has a propensity to migrate and potentially contaminate a public water supply.

The contaminant types evaluated in this study include: (1) DNAPLs (dense non-aqueous phase liquids); (2) LNAPLs (light non-aqueous phase liquids); (3) PNAs (polynuclear aromatics); (4) the heavy metals lead, mercury, and chromium VI; and, (5) polychlorinated biphenyls (PCBs). Within each group, specific contaminants were evaluated. These types of contaminants are common within this investigation's study area of the Rouge River watershed (Figure 1), and are used widely in the urban setting in products such as gasoline, diesel fuel, fuel oil, oil and other lubricants, solvents, cleaners, paints, pigments, and metal products (Rogers, 1996). The compounds listed in Table II are those most commonly detected within the watershed and also require evaluation by the Michigan Department of Environmental Quality as targeted compounds (MDEQ, 1995).

Toxicity values for these compounds were obtained from the US EPA Integrated Risk Information System (IRIS), which were updated in October 2004, and pertain to the oral ingestion of groundwater. Toxicity values for secondary exposure to 
TABLE II

Chemicals by contaminant group

\begin{tabular}{llll}
\hline DNAPL & LNAPL & PNAs and PCBs & Metals \\
\hline Tetrachloroethene (PCE) & Benzene & Naphthalene & Lead \\
Trichloroethene (TCE) & Toluene & Phenanthrene & Mercury \\
Cis 1,2-dichloroethene (DCE) & Ethylbenzene & Chrysene & Chromium VI \\
Trans 1,2-dichloroethene (DCE) & Xylenes (total) & Benzo(a)pyrene & \\
1,1,1-trichloroethane (TCA) & & Benzo[a]anthrocene & \\
Vinyl chloride & & Benzo[b[fluoranthene & \\
& & Benzo[g,h,i]perylene & \\
& & Benzo[k]fluoranthene & \\
& & Total PCBs & \\
\hline
\end{tabular}

groundwater, such as inhalation (i.e. while showering and bathing, etc.) and dermal contact (i.e., washing, etc.) were not considered in the toxicity values. Finley (1993) has demonstrated that secondary exposure pathways for groundwater can be significant for volatile organic compounds (VOCs) and could increase the exposure risk by as much as $50 \%$ under worst-case scenarios. However, without an exposurespecific quantitative analysis, the increase in exposure from secondary exposure can not be accurately estimated. Therefore, the VOC toxicity values utilized in this study should be considered base line values.

To obtain the integer value for mobility of each compound, two variables were calculated which include Henry's Law constant $(\mathrm{H})$ and retardation factor (R). Henry's Law constants were obtained from US EPA (1996) and Wiedemeier et al. (1999). The retardation factor employs the distribution coefficient using Equation (2).

$$
K_{\mathrm{d}}=(\mathrm{Foc})(\mathrm{Koc})
$$

where: $K_{\mathrm{d}}=$ distribution coefficient; Koc $=$ organic carbon partition coefficient $(1 / \mathrm{kg}) ; \mathrm{Foc}=$ fraction of organic carbon in soil $(\mathrm{mg} / \mathrm{mg})$.

Values for the organic carbon partition coefficient were obtained from Wiedemeier (1999) and the fraction of organic carbon in soil was obtained from Wiedemeier (1999) and US EPA (1996a).

Once the distribution coefficient was calculated, the Retardation Factor was calculated using Equation (3) (Wiedemeier 1999).

$$
R=1+\frac{\left(\rho_{\mathrm{b}}\right)\left(K_{\mathrm{d}}\right)}{\eta}
$$

where: $R$ is the retardation factor; $\rho_{\mathrm{b}}=$ bulk density of aquifer matrix $(\mathrm{mg} / \mathrm{g}) ; K_{\mathrm{d}}$ $=$ distribution coefficient; $\eta=$ effective porosity. 
Henry's Law constant is expressed in Equation (4).

$$
H=(\mathrm{VP})(\mathrm{MW})(\mathrm{Ws})
$$

where: $H=$ Henry's Law constant (unitless); $\mathrm{VP}=$ vapor pressure (atm); $\mathrm{MW}=$ molecular weight $(\mathrm{g} / \mathrm{mol}) ; \mathrm{Ws}=$ solubility in water $(\mathrm{mg} / \mathrm{L})$.

Once Henry's Law constant and the retardation factor were obtained, calculating the mobility of a specific compound is expressed as Equation (5).

$$
M=(H)(R)
$$

where: $M=$ mobility; $H=$ Henry's Law constant; $R=$ retardation factor.

Persistence values were obtained from Howard et al. (1991) and US EPA (1996a, 2000); they account for natural biological processes and are expressed as first order decay rates in years. These values represent default values, and in general, the first order decay rates used for each compound were a conservative selection of the decay rate spectrum listed.

Therefore, calculating the contaminant risk factor (CRF) is obtained by multiplying the inverse of a chemical compounds Toxicity $(T)$ by the inverse of its Mobility $(M)$ by its Persistence $(P)$ in the environment. Multiplying by the inverse of a chemical compound's toxicity and mobility is conducted to ensure the toxicity and mobility values remain a positive integer and the proper weighting of the values are achieved. The CRF equation is expressed as Equation (6).

$$
\mathrm{CRF}=\frac{1}{(T)} \frac{1}{(M)}(P)
$$

where: $\mathrm{CRF}=$ Contaminant Risk Factor; $T=$ toxicity; $M=$ mobility; $P=$ persistence (years).

Contaminant risk factors are calculated for each of the significant compounds within the contaminant groups listed in Table II. Once the CRF for each compound is calculated, they are averaged together by group to obtain an overall CRF for that group of compounds for each geologic unit in the River Rouge watershed (Table III). To ensure consistency with toxicity values obtained from the US EPA, potential chemical interactions within and between groups of contaminants were not evaluated and are not represented in the contaminant risk factors listed. Persistence values for the degradation of PCE to TCE, to Cis-1,2-DCE and Trans-1,2-DCE to vinyl chloride were calculated as a cumulative persistence because the degradation sequence for this group of compounds has been well established and is also significant given that the toxicity of the sequence generally increases as chemical degradation proceeds.

The contaminant risk factors for DNAPL compounds are significantly higher than the other contaminant groups. DNAPL compounds have higher contaminant 
TABLE III

Contaminant risk factors

\begin{tabular}{|c|c|c|c|c|c|}
\hline $\begin{array}{l}\text { Contaminant } \\
\text { type }\end{array}$ & $\begin{array}{l}\text { Geologic } \\
\text { unit }\end{array}$ & $\begin{array}{l}\text { Mean surface } \\
\text { risk value }\end{array}$ & $\begin{array}{l}\text { Subsurface } \\
\text { risk value }\end{array}$ & $\begin{array}{l}\text { Contaminant risk } \\
\text { factor }(\mathrm{CRF})\end{array}$ & $\begin{array}{l}\text { Total risk } \\
\text { factor }\end{array}$ \\
\hline \multirow[t]{5}{*}{ DNAPL $^{\mathrm{a}}$} & Clay & 0.04 & 11 & 333 & 343.04 \\
\hline & $\mathrm{SC}^{\mathrm{b}}$ & 33.7 & 15 & 773 & 821.7 \\
\hline & $\mathrm{SSC}^{\mathrm{c}}$ & 0.42 & 15 & 1091 & $1,106.42$ \\
\hline & Sand & 343.64 & 64 & 1419 & $1,826.64$ \\
\hline & Moraine & 240.54 & 50 & 1274 & $1,564.54$ \\
\hline \multirow[t]{5}{*}{ LNAPL $^{a}$} & Clay & 0.04 & 11 & 0.08 & 11.12 \\
\hline & SC & 33.7 & 15 & 0.42 & 49.12 \\
\hline & SSC & 0.42 & 15 & 0.47 & 15.89 \\
\hline & Sand & 343.64 & 64 & 0.72 & 408.36 \\
\hline & Moraine & 240.54 & 50 & 0.65 & 290.54 \\
\hline \multirow[t]{5}{*}{$\mathrm{PNAs}^{\mathrm{a}}$} & Clay & 0.04 & 11 & 0.0001 & 11.04 \\
\hline & $\mathrm{SC}$ & 33.7 & 15 & 0.0008 & 48.7 \\
\hline & SSC & 0.42 & 15 & 0.001 & 15.42 \\
\hline & Sand & 343.64 & 64 & 0.002 & 407.64 \\
\hline & Moraine & 240.54 & 50 & 0.002 & 290.54 \\
\hline \multirow[t]{5}{*}{ Lead } & Clay & 0.04 & 11 & 0.03 & 11.07 \\
\hline & SC & 33.7 & 15 & 0.3 & 49.0 \\
\hline & SSC & 0.42 & 15 & 0.34 & 15.76 \\
\hline & Sand & 343.64 & 64 & 1.1 & 408.74 \\
\hline & Moraine & 240.54 & 50 & 1.0 & 291.54 \\
\hline \multirow[t]{5}{*}{ Mercury } & Clay & 0.04 & 11 & 11.57 & 22.61 \\
\hline & $\mathrm{SC}$ & 33.7 & 15 & 25.26 & 73.96 \\
\hline & SSC & 0.42 & 15 & 27.7 & 43.12 \\
\hline & Sand & 343.64 & 64 & 30.95 & 438.59 \\
\hline & Moraine & 240.54 & 50 & 29.3 & 319.84 \\
\hline \multirow[t]{5}{*}{ Chromium VI } & Clay & 0.04 & 11 & 948 & 959.04 \\
\hline & $\mathrm{SC}$ & 33.7 & 15 & 2,080 & $2,128.70$ \\
\hline & SSC & 0.42 & 15 & 2,116 & $2,131.42$ \\
\hline & Sand & 343.64 & 64 & 2,300 & $2,707.64$ \\
\hline & Moraine & 240.54 & 50 & 2,235 & $2,525.54$ \\
\hline \multirow[t]{5}{*}{ PCBs } & Clay & 0.04 & 11 & 0.000026 & 11.04 \\
\hline & $\mathrm{SC}$ & 33.7 & 15 & 0.00026 & 48.7 \\
\hline & SSC & 0.42 & 15 & 0.0003 & 15.42 \\
\hline & Sand & 343.64 & 64 & 0.0009 & 407.64 \\
\hline & Moraine & 240.54 & 50 & 0.0008 & 290.54 \\
\hline
\end{tabular}

${ }^{a}$ Contaminant risk factors listed represent an average value of specific compounds listed in Table I. ${ }^{\mathrm{b}} \mathrm{SC}=$ Sandy clay.

${ }^{\mathrm{c}} \mathrm{SSC}=$ Sandy and silty clay. 


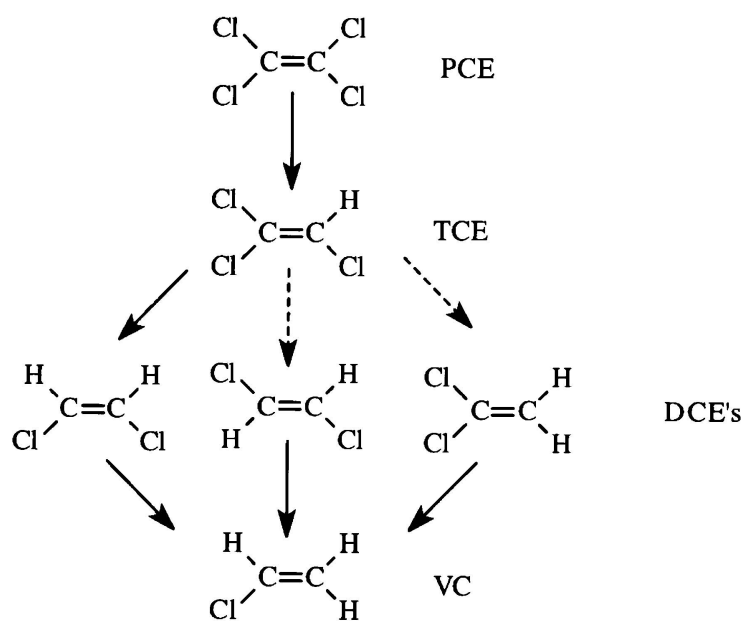

Figure 2. Degradation of chlorinated alkenes.

risk factors because, in general, DNAPL compounds are more toxic, more mobile, and much more persistent in the environment than the other contaminant groups. This persistence results from the degradation of chlorinated alkenes which follows a stepwise, anaerobic dechlorination series from perchloroethene (PCE) to vinyl chloride (VC) (Vogel and McCarty, 1985). This sequence is shown in Figure 2. Each reaction is first-order (the reaction rates depend on the concentration of the reactant) and are irreversible. The rates used in Table III were taken from Howard (1991) and US EPA $(1996,2000)$.

\subsection{SURFACE RISK}

Surface risk evaluations have traditionally used spatially generalized categories of land use, such as "industrial, commercial, or residential" to represent various levels of risk (Barringer et al., 1990; Eckhardt and Stackelberg, 1995; Secunda et al., 1998). The use of general land use categories is problematic for groundwater vulnerability assessment because of their inadequate spatial resolution; spatial resolution is defined as the smallest identifiable element in a sequence (Tobler, 1988). In urban and urbanizing areas, mixed land uses within small areas such as city blocks are common, so the variable risks may be obscured by generalization when the capture zones for wellhead protection are delineated. For example, the "10-year capture zone" is the sub-surface and surface areas from which water (and any contamination it carries) will reach the well over a time period of 10 years.

In this model, each site's total surface risk was derived through the summation of the existing contamination incidence rates present at establishments within a specified well capture zone (Kaufman, 1997). Contamination incidence rates for 
specific establishment types are obtained by: (1) assigning a Standard Industrial Code (SIC) (United States Office of Management and Budget, 1987) to each source of contamination appearing on the current Michigan Environmental Response Act list (MDEQ, 2002); (2) obtaining the total number of establishments in Michigan for each SIC code from the County Business Patterns (US Bureau of the Census, 1997); and, (3) dividing the number of contaminated sites with a specific SIC code by the total number of establishments in Michigan with that same SIC code.

The addresses of the contaminant sites are then geocoded (assigned latitude and longitude coordinates), and their associated data are appended with their SIC codes and corresponding contamination incidence rates. The SIC code is a four digit code: the first two digits identify a major group, such as agriculture, retail trade, or manufacturing; the third digit denotes industry groups within each major group, such as agricultural crop production; and the fourth digit identifies a specific industry code such as grain storage (United States Office of Management and Budget, 1987). Thus, given the exact locations of nearby establishments which possess varying, but known and commensurate incidence rates of contamination risk, it is possible to compute a parcel-level resolution of surface risk for any given site.

Darcy's Law is then used to develop the circular extents employed around the monitoring wells at the contaminated site (Kaufman et al., 2003). The scores of the incidence rates of the establishments within a radius representing the 20-year capture zone computed for the specific geologic unit are then summed. In order to scale the scores equivalently to the subsurface risks computed in the next section, the incidence rates are multiplied by 10 and converted to scores between $0-10$. A Geographic Information System (GIS) can be used for this procedure (Kaufman, 2000). In this investigation, the surface risks are shown in the third column of Table III and they represent the average value computed from the contaminated sites within the geologic units shown in Figure 1.

\subsection{SUBSURFACE RISKS}

To measure groundwater vulnerability, Murray and Rogers (1999) have developed a numerical rating system using a modified form of DRASTIC (Aller et al., 1987). The model uses weighting coefficients similar to the DRASTIC model for the geologic and hydrologic parameters (Table IV). The first parameter shown in Table IV is the depth to the shallow water table aquifer within the glacial deposits. The second parameter, occurrence of groundwater, is based on data collected from sites of environmental concern within the study area (Rogers and Murray, 1997). For example, a geologic unit with a less than $25 \%$ occurrence of groundwater means there is less than a one in four chance of encountering groundwater in a well drilled into this unit to a depth of 6 meters. The third and fourth parameters, areas of groundwater recharge and discharge provide a means of understanding the horizontal and vertical components of groundwater movement within the study area. Both of these parameters are related to parameters 5 and 6 , the textural characteristics and travel 
TABLE IV

Vulnerability matrix of subsurface risks

\begin{tabular}{|c|c|c|}
\hline $\begin{array}{l}\text { Parameter } \\
\text { identification number }\end{array}$ & Parameter description & $\begin{array}{l}\text { Rating } \\
\text { strength }\end{array}$ \\
\hline \multirow[t]{4}{*}{1} & Depth to groundwater & \\
\hline & Less than 3 meters & 10 \\
\hline & 3 to 10 meters & 5 \\
\hline & Greater than 10 meters & 1 \\
\hline \multirow[t]{4}{*}{2} & Occurrence of groundwater & \\
\hline & Greater than $75 \%$ & 10 \\
\hline & $25 \%$ to $74 \%$ & 5 \\
\hline & Less than $25 \%$ & 1 \\
\hline \multirow[t]{3}{*}{3} & Area of groundwater recharge & \\
\hline & Significant area of recharge & 10 \\
\hline & Insignificant area of recharge & 1 \\
\hline \multirow[t]{3}{*}{4} & Potential discharge of groundwater to surface water & \\
\hline & Significant area of discharge & 10 \\
\hline & Insignificant area of discharge & 1 \\
\hline \multirow[t]{5}{*}{5} & Composition of geologic units & \\
\hline & Gravel & 10 \\
\hline & Sand & 9 \\
\hline & Silt & 5 \\
\hline & Clay & 1 \\
\hline \multirow[t]{4}{*}{6} & Potential travel time to point of exposure & \\
\hline & Less than 10 & 10 \\
\hline & years 10 to 25 years & 5 \\
\hline & Greater than 25 years & 1 \\
\hline \multirow[t]{3}{*}{7} & Source of potable water & \\
\hline & Source of potable water & 10 \\
\hline & Not a source of potable water & 1 \\
\hline
\end{tabular}

time, which can be used to assess soil and solute transport properties of the nearsurface geologic materials. The seventh parameter, the source of potable drinking water, refers to whether the geologic unit is, or can be, a source of drinking water.

The weighted values for each geologic unit are added to determine a final relative index of unit sensitivity (Table V). These values are derived directly from hydrogeological investigations conducted at each site, but in some cases may represent a composite score based on a unit's heterogeneous materials. This heterogeneity of materials is evident from the extensive fieldwork performed by the authors within the study area which consisted of sampling the surface and subsurface soil (depth > 2 feet) at hundreds of dispersed sites. For instance, for parameter 5 (composition), 
TABLE V

Sensitivity scoring of subsurface risk

\begin{tabular}{|c|c|c|c|c|c|c|c|c|c|}
\hline \multirow[b]{2}{*}{ Geologic unit } & \multicolumn{7}{|c|}{ Parameters (from Table III) } & \multirow{2}{*}{$\begin{array}{l}\text { Total } \\
\text { score }^{\mathrm{a}}\end{array}$} & \multirow{2}{*}{$\begin{array}{l}\text { Relative } \\
\text { ranking }\end{array}$} \\
\hline & 1 & 2 & 3 & 4 & 5 & 6 & 7 & & \\
\hline Sand & 10 & 10 & 10 & 10 & 9 & 5 & 10 & 64 & High \\
\hline Moraine & 5 & 5 & 10 & 10 & 5 & 5 & 10 & 50 & Medium \\
\hline Sandy clay & 5 & 1 & 1 & 1 & 5 & 1 & 1 & 15 & Low \\
\hline Sandy and silty clay & 5 & 1 & 1 & 1 & 5 & 1 & 1 & 15 & Low \\
\hline Clay & 5 & 1 & 1 & 1 & 1 & 1 & 1 & 11 & Low \\
\hline
\end{tabular}

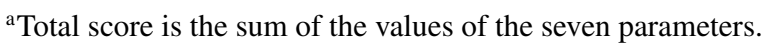

${ }^{\mathrm{b}}$ The rankings are based on these ranges for the total score: Low $=0-20$; Medium $=21-50$; High $>$ 50 .

the moraine is classified as silt with a midpoint value of 5 because of its mixture of sand, gravel, and clay. The sand and moraine units are substantially more vulnerable to groundwater contamination than the other units in the watershed because they are composed of highly permeable sediments with groundwater present and are in areas of the watershed subject to groundwater recharge.

\subsection{Plume EXTENT AND CONTAMINANT MASS}

After completing a subsurface investigation, the extent of contamination was directly measured using either a measuring tape or was determined using survey equipment in cases where the extent of contamination was extensive or extended beneath roadways or permanent structures (e.g., buildings). The subsurface investigations involved drilling soils borings and collecting and analyzing soil samples in a laboratory for the presence of contamination. The extent of groundwater contamination was evaluated by installing groundwater monitoring wells, and the groundwater samples were subsequently collected and analyzed in a laboratory for the presence of contamination.

The extent of contamination for organic compounds was evaluated to the corresponding US EPA analyte method detection limit listed required by the US EPA (1983). The required method detection limits listed by US EPA are typically in the order of 5 micrograms per kilograms for organic compounds. Table VI contains the analytical procedures used for the chemical groups present at the contaminated sites.

Evaluating the extent of contamination for metals required a different methodology than the organic compounds because metals naturally occur in the environment. Therefore, establishing background concentrations was required before evaluating the extent of actual metal contamination. The extent of metal contamination was typically evaluated to within one standard deviation of the mean of the evaluated background concentration. 
TABLE VI

Analytical methods

\begin{tabular}{ll}
\hline Chemical group/analyte & US EPA method \\
\hline DNAPL & 8260 \\
LNAPL & 8260 \\
PNAs & 8270 \\
PCBs & 8080 \\
Chromium & 6010 \\
Lead & 6010 \\
Mercury & 7470 \\
\hline
\end{tabular}

${ }^{\mathrm{a}}$ US EPA (1983).

Regulatory agencies require a measurement of the recovered or remediated contaminant mass at each site. The amount of contaminant mass remediated is calculated by first collecting periodic and representative samples of the recovered contaminant waste stream (usually water or air that was extracted by the remedial system, or soil in the case of excavation). Concentrations of contaminants were then determined in the samples collected through laboratory analysis. Once the concentration in each sample had been determined and calibrated through time using multiple sample collection and analysis episodes, the recovered or remediated contaminant mass was calculated by multiplying the contaminant concentrations measured by the laboratory in the samples by the total volume of air or water removed by the remedial system or the volume of soil excavated. This method is routinely conducted at each site where remediation is conducted over an extended period of time and usually involves remediating groundwater or large volumes of soil where it is not feasible or economical to remediate using other methods. Protocol also requires that duplicate samples be collected periodically to evaluate analytical variability.

In some cases where in-situ remedial measures were conducted (enhanced bioremediation or chemical treatment), contaminant mass was determined by conducting a more detailed subsurface investigation. This procedure involved analyzing more samples in the area to be remediated than would otherwise be conducted if active remediation was the selected remedial technology. A more intensive investigation is often required by the regulatory authorities at sites where an in-situ remedial method is conducted.

\subsection{MODEL CALIBRATION}

The data used to calibrate the model represent a subset from over 3000 sites of known or suspected environmental contamination. Project files compiled by the Michigan Department of Environmental Quality, which oversees the investigation 
TABLE VII

Model input data

\begin{tabular}{ll}
\hline Variable & Description \\
\hline $\begin{array}{l}\text { Contaminant } \\
\text { Type of facility }\end{array}$ & General chemical category (e.g., DNAPL) \\
$\begin{array}{l}\text { Geology } \\
\text { Remedial technology for } \\
\text { groundwater }\end{array}$ & $\begin{array}{l}\text { Primary surface soil unit (sand, clay) } \\
\text { Pollution abatement method (air sparging, pump and treat) }\end{array}$ \\
Remedial technology for & Pollution abatement method (excavation, capping, soil vapor \\
soil & extraction) \\
Mass (kg) & Total mass of contaminant found at the site \\
Cost & Total cost of remediation from project start to closure \\
Media remediated & At each site, soil or both soil and groundwater were remediated \\
Extent (meters) & Measured extent of the contamination \\
Cost/kg & Cost per kilogram of contaminant \\
Years of operation & Number of years the facility has been in operation \\
Subsurface risk factor & Geologic risk factors (as shown in Table IV) \\
Surface risk factor & Average surface risk for the geologic unit (as shown in Table III) \\
Contaminant risk factor & Obtained by multiplying the inverse of a chemical compound's \\
& toxicity by the inverse of its mobility by its persistence in the \\
environment (as shown in Equation (6))
\end{tabular}

and cleanup of hazardous waste sites in Michigan were supplemented by files generated by Clayton Group Services, a national environmental consulting firm located in Novi, Michigan.

Much of the input data for the model were obtained from measurements made at the sites and from laboratory analyses (Table VII). The risk factor values are those derived in this paper, and each risk component was included to assess its potential contribution to explaining the variation in remediation costs. Remediation cost data were obtained from public sources and were generally provided by the regulatory agency responsible for overseeing the site or the engineering/consulting firm conducting the work. The lack of complete remediation cost data limited the number of sites eligible for this analysis. A final total of 83 sites within the study area were selected, with these sites representing a variety of geologic units and contaminant categories. 


\subsubsection{Model Test}

One indicator of the validity of this model would be its ability to not only explain a high amount of the variation in remediation costs within the River Rouge study area, but to also explain a high amount of variation in remediation costs in other geological environments affected by different contaminants. Therefore, to validate the model 79 sites with varying geology and contaminants were used. The characteristics of these sites are shown in Table VIII; 69 of the 79 sites are located in North America, with many of these within the states of Illinois, Ohio, California, Kansas, and Wisconsin and the province of Ontario; 7 are from Europe (Italy, England, France, Belgium); 2 are from South Africa, and 1 is from Australia. These sites also exist within two additional geological environments - fluvial and lacustrine - and exhibit

TABLE VIII

Model validation site data

\begin{tabular}{|c|c|c|c|c|c|c|}
\hline $\begin{array}{l}\text { Contaminant } \\
\text { of concern }\end{array}$ & $\begin{array}{l}\text { Number } \\
\text { of sites }\end{array}$ & $\begin{array}{l}\text { Soil } \\
\text { type }\end{array}$ & $\begin{array}{l}\text { Number } \\
\text { of sites }\end{array}$ & $\begin{array}{l}\text { Geologic } \\
\text { setting }\end{array}$ & $\begin{array}{l}\text { Average } \\
\text { cost }(\$ / K g)\end{array}$ & $\begin{array}{l}\text { Average extent of } \\
\text { contamination from } \\
\text { source (meters) }\end{array}$ \\
\hline \multirow[t]{3}{*}{ DNAPL } & \multirow[t]{3}{*}{17} & Clay & 8 & $\mathrm{Fl}^{\mathrm{d}}, \mathrm{GL}, \mathrm{L}^{\mathrm{e}}$ & 474 & 40 \\
\hline & & $\mathrm{SC}^{\mathrm{a}}$ & 2 & $\mathrm{Fl}, \mathrm{GL}^{\mathrm{c}}$ & 224 & 95 \\
\hline & & Sand & 10 & $\mathrm{Fl}, \mathrm{GL}, \mathrm{L}$ & 98,269 & 810 \\
\hline \multirow[t]{4}{*}{ LNAPL } & \multirow[t]{4}{*}{17} & Clay & 10 & $\mathrm{Fl}, \mathrm{GL}, \mathrm{L}$ & 197.8 & 35 \\
\hline & & $\mathrm{SC}$ & 2 & $\mathrm{Fl}, \mathrm{GL}$ & 416 & 23 \\
\hline & & SSC & 1 & GL & 700 & 25 \\
\hline & & Sand & 4 & Fl, GL, L & 1,255 & 175 \\
\hline \multirow[t]{4}{*}{ PNAs } & \multirow[t]{4}{*}{17} & Clay & 13 & $\mathrm{Fl}, \mathrm{GL}, \mathrm{L}$ & 366 & 30.5 \\
\hline & & $\mathrm{SC}$ & 1 & GL & 125 & 22 \\
\hline & & $\mathrm{SSC}^{\mathrm{b}}$ & 1 & $\mathrm{Fl}$ & 340 & 20 \\
\hline & & Sand & 2 & $\mathrm{Fl}, \mathrm{GL}$ & 213 & 25 \\
\hline \multirow[t]{3}{*}{ Lead } & \multirow[t]{3}{*}{10} & Clay & 5 & $\mathrm{Fl}, \mathrm{GL}, \mathrm{L}$ & 190 & 125 \\
\hline & & $\mathrm{SC}$ & 4 & $\mathrm{Fl}, \mathrm{GL}, \mathrm{L}$ & 930 & 81 \\
\hline & & Sand & 1 & $\mathrm{Fl}$ & 500 & 100 \\
\hline \multirow[t]{2}{*}{ Chromium } & \multirow[t]{2}{*}{11} & Clay & 8 & $\mathrm{Fl}, \mathrm{GL}, \mathrm{L}$ & 474 & 40 \\
\hline & & Sand & 3 & $\mathrm{Fl}, \mathrm{GL}, \mathrm{L}$ & 81,713 & 2,133 \\
\hline \multirow[t]{2}{*}{ Mercury } & \multirow[t]{2}{*}{2} & Clay & 1 & GL & 1,000 & 10 \\
\hline & & $\mathrm{SC}$ & 1 & $\mathrm{Fl}$ & 3,000 & 75 \\
\hline \multirow[t]{2}{*}{ PCBs } & \multirow[t]{2}{*}{5} & $\mathrm{SC}$ & 1 & $\mathrm{Fl}$ & 1,200 & 5 \\
\hline & & Sand & 4 & $\mathrm{Fl}, \mathrm{GL}, \mathrm{L}$ & $2,053.9$ & 13.75 \\
\hline
\end{tabular}

${ }^{\mathrm{a}} \mathrm{SC}=$ Sandy clay.

${ }^{\mathrm{b}} \mathrm{SSC}=$ Sandy and silty clay.

${ }^{\mathrm{c}} \mathrm{GL}=$ Glacial lacustrine.

${ }^{\mathrm{d}} \mathrm{Fl}=$ Fluvial

${ }^{\mathrm{e}} \mathrm{L}=$ Lacustrine. 
two additional contaminants - mercury and PCBs. Site data were obtained from publicly available information, environmental consultants, and industrial sources, and was cross referenced whenever possible. Similar methods for measuring the plume extent and contaminant mass present at the site were followed.

The search for the independent variables with the best explanatory power was facilitated through a stepwise linear regression procedure. The variables listed in Table VII were included in the first iteration. The initial inclusion alpha level was set at 0.15 , and the statistical tests for the final model parameters were performed at the 0.05 level of significance.

\section{Results and Discussion}

Early iterations of the stepwise regression procedure retained plume extent and a summation of the CRF, surface, and subsurface risk scores. The explained variance in remediation cost was $11 \%$. After looking at the distributions of these independent and dependent variables, it was learned they were positively skewed. After a logarithmic transformation, and the multiplication of the risk values by the plume extent, the explained variation in remediation costs rose to $71 \%$. The multiplication of the risk values by the plume extent was performed to combine the effect of dispersion (plume extent) with the severity (CRF - contaminant risk factor) of the contamination. Larger plumes with more intense contamination (which is represented by the CRF) would be harder - and thus more expensive - to remediate. This is why the explained variance increases significantly when this term is added to the model. When the contaminant mass was added to the model and multiplied to the prior result the explained variance rose to $76 \%$. The outcome is represented by Equation (7) and shown in Figure 3.

$$
\operatorname{lgcost}=5.107+0.4949 \text { lgriskweight }
$$

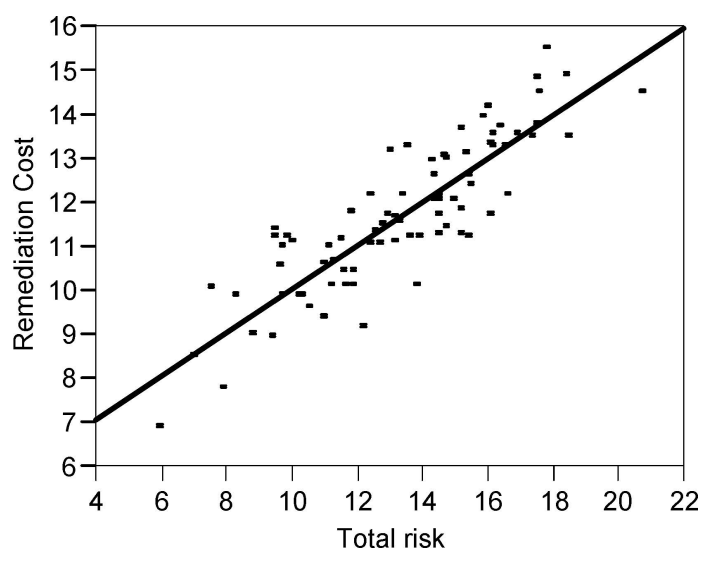

Figure 3. Regression of total risk on remediation cost. 
where: lgcost is the log of the total remediation costs; lgriskweight is the summation of the CRF, surface and subsurface risk scores multiplied by the plume extent and contaminant mass measurements taken at each site. Conceptually and empirically, this composite independent variable can be characterized as total risk.

Statistically, the model is strong $\left(F=261.3, R^{2}=76, p<0.0001, n=83\right)$. There is likely some degree of interaction between the risk factors (CRF, surface, subsurface) and the plume extent and contaminant mass. If a contaminant has higher mobility and persistence, it will create a plume of greater distance. Likewise, higher persistence among certain contaminant categories such as DNAPLs would necessarily lead to their measured mass being higher. These fate and transport characteristics help to account for the explanatory power of the distance and mass factors in the model.

When Equation (7) was tested against the 79 sites across the world, there was a very strong statistical correlation between the model's estimated values for remediation cost and the actual cost values $(r=90 ; F=334.1, p<0.0001)$ (Figure 4). This result provides a good indication of the strength of the model, since there are many other potential factors which may influence a site's remediation cost. For example, there is the presence of free product at the site, which indicates free phase product or liquid exists at a thickness of 0.11 inches or greater. There is also an entire spectrum of regulatory differences, which include Resource Conservation and Recovery Act (RCRA) corrective actions, agency orders, listed hazardous waste issues, Toxic Substance Control Act (TSCA) disposal restrictions, and land ban restrictions. Moreover, there are state-to-state and country-to-country procedural differences with respect to site remediation.

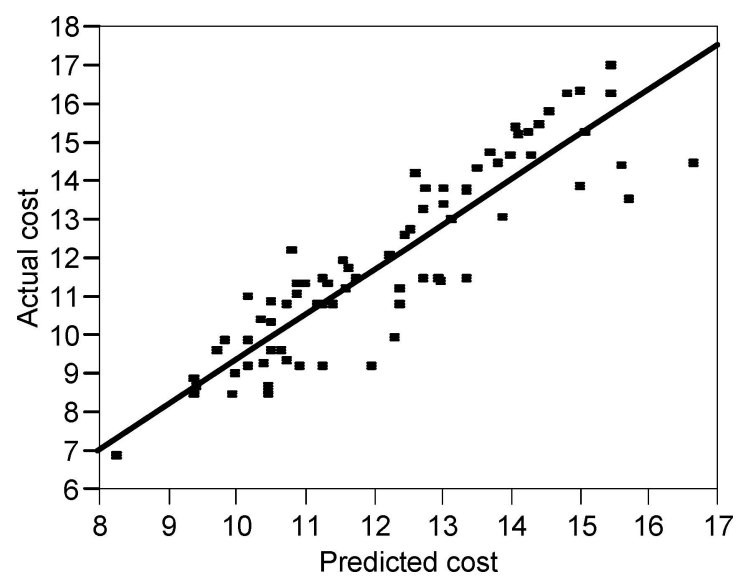

Figure 4. Plot of actual vs. predicted remediation costs. 


\subsection{IMPLICATIONS FOR MANAGING SITE REMEDIATION}

The new federal SBLRBRA allows for a portion of grants to be used to purchase environmental insurance (Woll et al., 2003). With the better estimation of remediation costs, insurance costs could be possible be reduced, and this chain of events could help make brownfield redevelopment less risky and more profitable.

Since there are so many brownfield sites within urban areas, an assessment of the relationship between environmental risk and remediation costs can help communities prioritize their cleanup efforts. In addition, the siting of future public supply water wells can be improved by identifying those areas where lower risks of contamination and environmental liability are present.

The results of this study demonstrate that the cost of remediation is directly related to contaminant type and subsurface geology and that certain combinations of contaminants and geologic environments are especially costly and in effect produce a synergistic effect on the cost of remediation and extent of contamination. This is evident when a contaminant such as DNAPL, which is potent, mobile, and persistent is released into a geologic environment that is ideal for migration (i.e., sandy soils). Under this scenario, the contamination quickly spreads, perhaps beyond the facility property boundary, and then may have the potential to migrate to a point where a human exposure is realized, such as a surface water body or a potable groundwater supply. As shown in Table VIII, the average cost to remediate DNAPL or CrVI in a geologic environment composed of sand is greater than $\$ 80,000$ per kilogram, whereas to remediate the same contaminants in a clay geologic environment is less that $\$ 500$ per kilogram.

When conducting brownfield assessments it is important to consider the combined effects of subsurface geology and specific types of contamination. There is the potential of a synergistic effect when combining contaminants with a high $\mathrm{CRF}$ and a subsurface geologic environment that does not significantly impede the migration of these contaminants. Thus, the resulting synergistic effect greatly increases the extent of the contamination, which will then increase the likelihood that a completed human pathway may be realized. Therefore, development of a brownfield plan should consider the subsurface geologic environment beneath the facility or region being evaluated along with historical use of hazardous substances. Other criteria should also be considered, such as the presence of potable groundwater supplies, proximity to surface water bodies, and other potential exposure pathways. Although beyond the scope of this study, further study of the synergistic effects between local geologic conditions and specific contaminants is needed.

\subsection{MODEL EFFICACY}

Several factors not considered in this research may prove to be important as testing and application of the model proceeds. For instance, there is the possibility 
that other contaminants not studied will be present at the sites, natural attenuation of current contamination will occur, and different costing mechanisms will exist in other geographical regions. Nevertheless, the model displays good predictive characteristics across a broad variety of environments, and this speaks well of its robustness.

\section{Conclusion}

This model provides the potential to accurately estimate remediation costs at contaminated sites in diverse geological settings. A combination of risks from surface, subsurface, and specific contaminants is used in conjunction with plume extent and contaminant mass to derive the total risk present at a site. Applications for the model include the prioritization of cleanup costs and the risk assessment associated with locating future water wells. Potential benefits realized from this model may include the reduction of costs during brownfield transactions. The application of this model to a wide range of sites (with high geological variability) and the resulting high amount of explanatory power illustrates the potential robustness of the model.

Any model needs more than one application to ensure its validity. Application of this model in other geologic environments and with other contaminant classes will help improve its efficacy. Identification and quantification of other factors which can influence the remediation cost at contaminated sites is another logical measure.

\section{References}

Aller, L., Bennett, T., Lehr, J. H., Petty, R. J. and Hackett, G.: 1987, DRASTIC: A Standardized System for Evaluating Ground Water Pollution Potential Using Hydrogeologic Settings, Ada, Oklahoma: U.S. EPA-600/2-87-035.

Aziz, J. J., Ling, M., Rifai, H. S., Newell, C. J. and Gonzales, J. R.: 2003, 'MAROS: A decision support system for optimizing monitoring plans', Ground Water 41, 355-367.

Barringer, T. H., Dunn, D., Battaglin, W. A. and Vowinkel, E. F.: 1990, 'Problems and methods involved in relating land use to groundwater quality', Water Resour. Bull. 26, 1-9.

Bartsch, C., Andress, C., Setzman, J. and Cooney, D.: 1991, New Life for Old Buildings: Confronting Environmental and Economic Barriers to Industrial Reuse, Northeast-Midwest Institute, Washington, DC.

Bedient, P. B., Hanadi, S. R. and Newell, C. J.: 1999, Ground Water Contamination: Transport and Remediation, 2nd edn., Prentice Hall, NJ.

Bergquist, S. G. and MacLachlan, D. C.: 1951, Guidebook to the Study of Pleistocene Features of the Huron-Saginaw Ice Lobes in Michigan, The Glacial Field Trip of the Geological Society of America, Boulder, CO.

Dorr, J. A. and Eschman, D.: 1988, Geology of Michigan. The University of Michigan Press, Ann Arbor, MI, $476 \mathrm{pp}$.

Eckhardt, D. A. V. and Stackelberg, P. E.: 1995, 'Relation of groundwater quality to land use on long island, New York', Ground Water 33, 1019-1033. 
Farrand, W. R.: 1982, Quaternary Geology of Southern (\& Northern) Michigan, Michigan Department of Natural Resources, Geological Survey Division, Lansing, MI, 1:500,000.

Farrand, W. R.: 1988, The Glacial Lakes Around Michigan, Michigan Department of Natural Resources Bulletin No. 4, Lansing, MI.

Finley, E. T.: 1993, 'Evaluating the adequacy of MCLs as a health-protective cleanup goal: An analysis based on Monte Carlo techniques', Regulatory Toxicology and Pharmacology 18(3), 438-455.

Hassan, A. E.: 2004, 'Validation of numerical ground water models used to guide decision making', Ground Water 42, 277-290.

Howard, H. H., Boethling, R. S., Jarvis, W. F., Meylan, W. M. and Michalenko, E. M.: 1991, Environmental Degradation Rates, Lewis Publishers, New York, NY, 725 pp.

Irwin, S.: 2001, 'A Brownfield Restoration Primer', Environ. Protection 12, 38-43.

Kaufman, M. M.: 1997, 'Spatial assessment of risk to groundwater from surface activities', Pap. Proc. Appl. Geogr. Conf. 20, 135-142.

Kaufman, M. M.: 2000, 'Automated procedure for groundwater risk assessment from surface sources', Pap. Proc. Appl. Geogr. Conf. 23, 277-284.

Kaufman, M. M., Murray, K. S. and Rogers, D. T.: 2003, 'Surface and subsurface geologic risk factors to ground water affecting brownfield redevelopment potential', Journal of Environmental Quality 32, 490-499.

Leverett, F. B.: 1911, Map of the Surface Formations of the Southern Peninsula of Michigan, Geological survey of Michigan, Publication 25, Lansing, MI, 1:1,000,000.

MDEQ, Michigan Department of Environmental Quality: 1995, Operational Memorandum Number 8, Lansing, Michigan, p. 108.

MDEQ, Michigan Department of Environmental Quality: 2002, Michigan Sites of Environmental Contamination. http://www.deq.state.mi.us/tri/02facility.asp, accessed 12/20/04.

Mozola, A. J.: 1969, Geology for Land and Groundwater Development in Wayne County, Michigan. Report of Investigation 3, State of Michigan Dept. of Natural Resources, Geol. Survey, Lansing, MI.

Murray, K. S. and Rogers, D. T.: 1999, 'Groundwater vulnerability, brownfield redevelopment and land use planning', Journal of Environ. Plann. Manage. 42, 801-810.

OTA (Office of Technology Assessment): 1995, State of the States on Brownfields: Programs for Cleanup and Reuse of Contaminated Sites. Congress of the United States, Washington, DC.

Rieck, R. L.: 1981, Glacial drift thickness, Southern Peninsula. Plate 15. Hydrogeologic Atlas of Michigan. Western Michigan University, Kalamazoo, MI.

Rieck, R. L.: 1981a, Community public water supplies. Plate 22. Hydrogeologic Atlas of Michigan. Western Michigan University, Kalamazoo, MI.

Rogers, D. T.: 1996, Environmental Geology of Metropolitan Detroit. Clayton Environmental Consultants, Novi, MI.

Rogers, D. T. and Murray, K. S.: 1997, 'Occurrence of groundwater in metropolitan Detroit, USA', in Groundwater in the Environment, Vol. 1, A.A. Balkema Publishers, Rotterdam, The Netherlands, pp. $155-160$.

Rogers, D. T., Murray, K. S. and Kaufman, M. M.: 2005, 'Assessment of groundwater contaminant vulnerability in an urban watershed in Southeast Michigan USA', in K. Howard (ed), Matthias Eiswirth Memorial Volume, A.A. Balkema Publishers, Rotterdam, The Netherlands, in press.

Secunda, S., Collin, M. L., Melloul, M. L. and Abraham, J.: 1998, 'Groundwater vulnerability assessment using a composite model combining DRASTIC with extensive agricultural land use in Israel's Sharon region', Journal of Environmental Management 54, 39-57.

Sherzer, W. H.: 1916, Geologic Atlas of the United States, Detroit Folio No. 205, United States Geological Survey, Reston, VA 1:62,500.

Simons, R.: 1999, 'How many brownfields are there? An economic base contraction analysis of 31 U.S. cities', Public Works Management and Policy 2, 267-273. 
Singer, M.: 2000, 'New ways to pay for property restoration', Public Manage. 83, 17-20.

Suarez, M. P. and Rifai, H. S.: 1999, 'Biodegradation rates for fuel hydrocarbons and chlorinated solvents in groundwater', Bioremediat. J. 3, 337-362.

Tobler, W.: 1988, 'Resolution, resampling and all that', in H. Mounsey and R. Tomlinson (eds), Building Database for Global Science, Taylor and Francis, London, pp. 129-137.

United States Office of Management and Budget: 1987, Standard Industrial Classification Manual, U.S. Gov. Print. Office, Washington, DC.

US EPA (United States Environmental Protection Agency): 1983, Test Methods for Evaluating Solid Waste (SW-486), Washington, DC.

US EPA: 1989, Transport and Fate of Contaminants in the Subsurface, EPA/625/4-89/019, Washington, DC, $148 \mathrm{pp}$.

US EPA: 1996, Bioscreen. Natural Attenuation Decision Support System, Version 1.4, Office of Research and Development. Washington, DC, 65 pp.

US EPA: 1996a, Soil Screening Guidance: Technical Background Document. Office of Solid Waste and Emergency Response. Washington, DC, 230 pp.

US EPA: 1997, Expediting Cleanup and Redevelopment of Brownfields: Addressing the Major Barriers to Private Sector Involvement - Real or Perceived, Washington, DC.

US EPA: 2000, Biochlor, Natural Attenuation Decision Support System, Version 1.0, Office of Research and Development, Washington, DC, $45 \mathrm{pp}$.

Vogel, T. M. and McCarty, P. L.: 1985, 'Biotransformation of tetrachloroethylene to trichloroethylene, dichloroethylene, vinyl chloride, and carbon dioxide under methanogenic conditions', Appl. Environ. Microbiol. 49, 1080-1083.

Wang, T. A. and McTernan, W. F.: 2002, 'The development and application of a multilevel decision analysis model for the remediation of contaminated groundwater under uncertainty', Journal of Environ. Management 64, 221-235.

Wiedemeier, T. H., Rifai, H. S., Newell, C. J. and Wilson, J. T.: 1999, Natural Attenuation of Fuels and Chlorinated Solvents in the Subsurface, John Wiley \& Sons, Inc., New York, NY, 617 pp.

Woll, B., Mack, J., Ellerbusch, F. and Vetter, J. R.: 2003, 'Facilitating brownfields transactions using triad and environmental insurance', Remediation 13, 113-130. 